\title{
痛みの発生機序とその伝達機構
}

Mechanism and transmission of Pain

広島大学医学部麻醉・蘇生学教室 弓削 孟文

「痛みとは実際の, または潜在する組織損傷を伴う不快な感覚的, 精神的な経験」である。 外傷などの侵害刺激として認識する組織障害がはっきりしている場合は当然「痛み」を感 じるが組織損傷がはっきりしない場合にも我々はしばしば「痛み」を感じる。

また，いずれの場合も精神的な反応が「痛み」の程度や種類に大きく影響するネコの superficial radial nerve を電気刺激すると, 軽い電気刺激で A $\alpha, \beta$ 䋐維の compaound action potential が得られ，さらに上げると A $\delta$ 絾維の action potential が得られ， かなり遅れて強い電気刺激で $\mathrm{C}$ 繊維の action potential がでてくる。

「痛み」刺激を中枢に伝達する末梢神経繊維は前述した $\mathrm{A} \alpha$ 繊維と $\mathrm{C}$ 瀻維である。 これらの神経線維は知覚神経や自律神経, つまり交感神経や副交感神経にも独立して存在 する。

これらの刺激は各々の求心繊維を伝導し脊髄後角の WDR neuron (Wide Dynamic Range Neuron）に伝えられる。

WDR neuronで「入力刺激」の性質の識別が行われ，「触った」「压迫した」「冷たい」 「熱い」「痛い」等の固有の感覚が選択識別され, より中枢神経へと伝えられて行く。 ところで, 痛みには傷害受容性疼痛, 神経因性疼痛, 心因性疼痛がある。

侵害受容性疼痛は組織が実際に侵害を受けた時に起こる痛みであり体性痛と内藏痛に分け られる。神経因性疼痛は神経系に内在する病変による痛みであり, 三叉神経痛やカウザル ギーや反射性交感神経性萎縮症等難治性の疼痛である。心因性疼痛は痛みを起こす身体的 な原因がない痛みである。

$\overline{M E M O}$ 
侵害刺激がなぜ「痛み」として中枢へ伝達されるのであろうか？

組織が侵害刺激で侵害を受けると局所に炎症反応が起こることはよく知られている。 炎症反応によって局所に産生される種々の化学物質が侵害受容器を刺激する痛み刺激を起 こす化学物質としてヒスタミンやキニン類, プロスタグランデン等が古くから知られてい る。これら明らかな侵害によって生じる炎症による痛みは急性痛として理解しやすい。 神経因性疼痛は持続する神経源性炎症（化学的炎症）が主因と考えられる難治性慢性疼痛 である。この疼痛には交感神経系が深く関与していると考えられている。交感神経求心路 を伝わってくる刺激は中枢へ伝えられるだけでなく, 春䯣や延䯣のレベルで交感神経遠心 路への反射性刺激をおこし, 頻脈や血圧上昇等の自律神経反射を招来するだけでなく神経 源性炎症の発生因子ないしは促進因子となりうる。

器質的な原因の無い痛みを心因性疼痛とするが, 人間の「心」と「射」は複雑に絡み合っ て調節されており, 我々が疼痛外来で接触する患者の多くは心因性の促進因子をかかえて いることあ事実である。

我々が痛みの治療をする際には, これら痛みの発生原因と伝達機序に関する基礎知識を充 分に認識した上で対応することが大切である。

キーワード : 痛み刺激, 発痛物質, 侵害受容性疼痛, 神経因性疼痛, 心因性疼痛 MEMO 


\section{鍼尒・漢方の効果についての実験的・超微形態学的研究， 特に「生体防御機能増強効果」について}

Ultrastructural Studies on the Effects of Oriental Medical Treatments Including Acupuncture, Moxibustion and Chinese Herbs.

名古屋市立大学名誉教授・明治鋮尒大学大学院教授 渡 仲三

東洋医学の鍼尒や漢方が有効であることは今さら言うまであないが，西洋医学的立場か らこれを見た場合に，その有効性が疑問視され，ないがしろにされている場合もしばしば ある。われわれはこの点を解明すべく, 二十数年前から東洋医学的治療の有効性の解明に ついて，主として電子顕微鏡を用いて研究して来た。それらの研究成果を，会員の皆様に 出来るだけ解り易く解説したいと考えている。

研究方法および成果 : (1) 漢方薬甘草のエキス成分，グリチルリチンの効果についての研 究: グリチルリチンがアレルギー性疾患に有効であることは古くから知られていたが, これが肝傷害に有効であることは，疑問視されていた。われわれはマウスを用い，こ れに四塩化炭素や化学発癌物質を投与して肝傷害を若起せしめると共に，これにグリ チルリチンを筋注して，グリチルリチンの効果を検索したところ，グリチルリチンが 肝傷害を治癒せしめ，また肝臓癌を防止することが証明された。

(2) ハリの効果についての研究 : 主としてマウスを用い，これに四塩化炭素，塩化第二 水銀，アロキサンなどを投与して，肝・膵・腎傷害などを惹起せしめると共に，これ に，八リ治療を施し，その効果について超微形態学的に検索した。また，マウスの老 化による肝・膵傷害についても，2 年間にわたって，ハリの老化防止への効果を検索

し，極めて興味ある成果をえた。

（3）炎の効果についての研究：マウス，ラット，イモリなどに，四塩化炭素やストレプ トゾトシンなどの毒物を投与すると共に，この動物の頭頂部（ヒトの百会に相当する 経穴）に施尒を行い，肝臓および膵臓を観察したところ，众に，上記の毒物に対する 解毒作用のあることや，免疫力を増強する効果のあることが証明された。 
考察とまとめ: 動物に種々の毒物を投与して, 実験的疾患モデルを作成したり, 動物の老 化に対して，東洋医学の鍼众や漢方が有効であるか否かを検索した結果，その有効性が 超微形態学的に証明された。特に興味ある結果は, これらの東洋医学的治療が, いずれ も, 生体防御系に対して反応し, 治療効果を現すということである。特に, 膵藏間質組 織内や皮下に，われわれが1982年に発見，「脂質貯蔵細胞（lipid ‥storing cell）之命 名した解毒細胞が, 鍼尒や漢方治療によって活性化し, その解毒力を增すと共に, 免疫 担当細胞であるマクロファージや, リンパ球, 形質細胞などと接触して, 広義の生体防 御機能を高める働きのあることが解った。「脂質眝蔵細胞」は本来, その保有する脂質 滴の中に, 生体の中に出現した毒物を補足, 処理する働きがあるが, さらにこれが, 広 義の生体防御に関与することは極めて興味深い。[謝辞：これら一連の研究は, 主とし て, 名古屋市立大学医学部第一解剖学教室, 東洋医学研究所 (黒野保三所長) および一 部の研究は，明治鍼尒大学での共同研究である。]

干458 名古屋市緑区六田 2-72- $2 \quad \boldsymbol{8} 052-622-1087 \quad$ Fax 052-622-1203 キーワード：鍼尒，漢方，グリチルリチン，超微形態，「脂質眝蔵細胞」 MEMO 


\section{胸腹証について}

Thoraco-Afdominal SHO

社日本東洋医学会 小川 新

胸腹証の研究する目的は, 治療医学に必要な胸腹証を会得するためであり, それは即座 に役立つからである。

大切なことは (1) 時間的経過を無視しないことである。

（2）寒熱を見逃さないことである。

(3) 手脈, 足脈, 人迎脈之の関係をみなければならない。

（4）間違っている胸腹証について

(1) 胸脇苦満と脇下硬

(口) 心下㾂硬と心下堅乃至心下硬

(文) 心積と脾積

(二) 下腹の腹証と三焦湿熱, 虚寒について

以上のことを実技を主として公開したい。

$\frac{\text { キーワード }}{\text { MEMO }}$

1. 時間と空間のこと

2. 寒熱

3. 手脈, 足脈, 人迎脈

4. 胸脇苦満

5. 上焦の実熱, 虚熱, 虚寒 


\section{バイオエシックスから見た 地球にやさしい医療}

京都大学名誉教授・日本生命倫理学会会長・東京慈恵会医科大学客員教授 京都女子大学宗教文化研究所教授・国際バイオエシックス研究センターディレクター

星野 一正

医療を円滑に行うには，特に医師と患者との人間関係があたたかい信頼関係にあること が重要であるが, 患者を診療し, 看護し，ケアする側の医療関係者同士の人間関係が円満 かっ円滑にいっていることあ患者に対して大切であることは言うまであないことである。 患者にとっては, 医療関係者は, 病院や医療機器という物的環境に劣らず, 重要な意味 をもつ人的環境であり, むしろ後者が患者の生命や精神生活に及ぼす悪い影響の方がより 問題である。よく耳にする医師と看護婦の不仲や互いの不信感が患者に悪い影響を及ぼす ことを自覚しなければならない。西洋医学にも鍼尒学にも，患者を楽にしてあげるのに， それぞれ別の意味での限界があることを認識し, 限界があるからと一方を切り捨てずに, 患者のために両者が補い合えるところは協力して, 患者の医療に役立てるべきではないか と思わ杖。患者あっての医療であり，患者のための医療であることが，基本である。

キーワード

MEMO 


\section{転換期の鍼尒學}

A Turning Polnt in Acpuncture and Moxibustion Rcsearch

明治銊尒大学大学院 研究科長 本間 三郎

世界観をつくる意識というものは東西において相違している。東での意識は脳という物 質とは関係ない，精神的なむの，片や西洋での意識は脳という実在する物質の所産である とする。意識そのものを第一義的に考えるのと，物質を主体と考える理念である。東は東， 西は西，両者の理念は決してあいまみえることのできないあのといわれている。この架橋 のできない東西世界観を基にして生まれた東西の両医学も同一の軌道に乗ることはできな い。このことは鍼尒治療と西洋医学とが相互に理解することができなかったこれまでの経 緯からして明らかである。そういった状況のなかにあって今回明治銊尒大学大学院に博士 課程が開設され，3年後に鍼尒學博士が誕生することとなった。

わが国は明治以来西洋医学の学術研究体制にある。医学研究は身体を構成する物質を測 定することを基として展開され，その考え方は科学的であるという。それだけに科学の進 歩が急速過ぎると非人間的な研究に陥る傾向にあるとされている。このような科学的研究 の成果である博士論文に，理念の異なる鍼炎の研究が入り得るものであろうか。鍼尒学の 博士論文は大学院でどのように審査され，その合否が決定されるというのであろうか。博 士課程の開設にあたり明治鍼炎大学では次のような研究目標を定めた。

鍼尒学研究は西洋医学と先端科学技術と整合性をとりつつ, 鍼尒学の独自の発展を図る あのとした。従って経穴や経絡についても解剖学的に実証を，打鍼の鎮痛効果についてす 西洋医学との間に整合性がとれているかを確かめていく。最近のMRIやPETなどの先端 科学技術による人間の脳機能研究にも鍼众研究は躊躇することなく仲間入りし, 脳におけ る意識の発生機構の研究に迫っていかねばならない。これまでの鍼炎治療は患者の意識で ある訴えに基づいて，経穴も経絡もその身体的位置が定められてきた。しかしわれわれの 意識は, 脳との相互関係に基づいて発生しているとする最近の科学的知見がある。この知 見からすると，これまでの経穴や経絡の身体図は，訴えである脳の意識の投影図となるで あろう。脳機能研究の成果に基ずくこの新しい視点から鍼负治療を改めて見直す段階にき ている。そこに意識を第一義的に考えてきた東洋の鎣智による鍼尒学の独自の発展が今後 期待されるし，それはまた脳という物質の研究である西洋医学之十分に整合性のとれた研 究となるであろう。鍼尒学の研究は正にその転換期に入っているといえよう。

8ా043-242-2769

キーワード：鍼尒，経穴，経絡，意識，脳 


\title{
チェルノブイリ被曝小児にみられる 甲状腺癌の実情と現地診療
}

Actual state of children's thyroid cancer in Chernobyl and diagnosis and treatment at the Spot

\author{
広島大学医学部第二外科 武市 宣雄 土肥 雪彦 \\ 広島大学原爆放射能医学研究所環境变異佐藤 幸男
}

【目的】チェルノブイリ原発事故と小児甲状腺癌の関係解明と現地での診療について 【材料之方法】1991年以来1994年10月迄に 9 回現地を訪れ，小児甲状腺癌発生数（手術例） の確認，癌部之非癌部の甲状腺の鏡検（84例)，300例以上の小児甲状腺検診を行い，甲 状腺手術にあ加わった。

【結果と考察】小児甲状腺癌の発生は1990年から急増しており，これは I -131 線量の高 い地域，低ヨード地域で著名である。乳頭癌が殆んどだが低分化型の混在が目立つ。検 診中にリンパ球浸潤と線維化が著名で，硬く触れるタイプが多くみられ，これを“硬化 性甲状腺腫”之名付けた。更にこの硬化性甲状腺腫と “硬化性甲状腺癌”之の関係も推 察された。硬化性甲状腺腫の多くは血中自己抗体を伴わず，橋本氏病とは異なる機序が 推察された。その他の尿中ヨード, 血中甲状腺ホルモン, 甲状腺組織, 胎児甲状腺, 癌 遺伝子等の結果を含めて，I-131被曝と小児甲状腺癌発生の関係を報告する。これに 加えて, 現地での検診, 手術の体験, 検診一治療一追跡調查の一貫システムの必要性, とその為の末端之基幹病院の協力作り，検診車と医療援助の必要性について説明する。

于734 広島市南区霞 $1-2-3$

8ా082-263-1891

キーワード：チェルノブイリ，原発事故，小児甲状腺癌， I -131 MEMO 


\section{チェルノブイリ原発事故による放射線障害児を \\ 経絡(経穴)への貼薬治療で救おう}

(社日本東洋医学会理事 十河 孝博

1986. 4. 26に発生したチェルノブイリ原発事故は永久に回復出来ないような障害を周 辺住民に与えています。ことに免疫機構の未完成な幼い子供達への影響は想像を絶するも のがあります。

放射性物質の污染はチェルノブイリ原子力発電所のあるウクライナにとどまらず，ベラ ルーシ共和国からヨーロッパに及ぶ広汎な地域に拡がっており，しかも政治的，経済的な 事情もあって，ほとんどの住民は污染地域を離れて非污染地域に移住することは出来ず, 污染した空気を吸い，污染した水や食物を摂取して生活しなくてはなりません。

我々は 3 年前からウクライナの放射線障害児を対象に伝統医学によって救う方法はない ものかと治療方法の模索を行っています。

現地からの報告によりますと, 污染地域のほとんどの子供が何らかの症状を訴えている と云うことです。例えば，体がだるい，疲れやすい，根気が続かない，鼻血がよく出るな どがよくみられ，そのために学校の授業は午前中だけで終りにするとのことです。

我々がとくに問題視しているのは, 半数以上の子供に甲状腺障害が認められると云うこ とです。この甲状腺障害は癌化の恐れがあるばかりでなく，成長期にある子供の心身に大 きな影響を与えます。

ウクライナの専門家は甲状腺障害の認められる子供は国内だけでも10〜20万人以上に及 び, 空気や水や食物などの污染が除かれない限り, 今後さらに甲状腺障害児は増えて行く であろうと云っています。

$\frac{\text { キーワード }}{\mathrm{MEMO}}$ 


\section{東洋医学の生命観からみた鍼尒医学の特徵について}

Characterlstics of Acupuncture and Moxibustlon Medicine vlewed from Theory of life in Oriental Medicine.

$$
\text { 明治鍼尒大学第一東洋医学臨床教室 矢野 忠 }
$$

演者は本シンポジゥムのテーマである“地球にやさしい鍼尒”を“人にやさしい銊尒” として理解した。演者の云う “やさしさ”とは相手を尊重するという意味である。

鍼尒医学は，薬物療法のようにある種の薬効で病変を人為的に操作することはせず，あ くまで本来の望ましい状態に復帰できるように，内在する治癒システムに働きかけ，その 機能が存分に発揮できるように援助することを基本としている。そして, 治癒効果を効率 的に発現させるために内在性治瘉システムを活かすさまざまな手法を駆使する。それは “場”の効果であったり，イメージであったり，手技であったりする。

このような鍼炎医学の特徴は, ひとえに“人の生きている状態”を重視する東洋医学の 考え方によるものと考える。演者は, 東洋医学での “生きている状態”とは, 外部と内部 との情報交流によって自己組織化することであると捉える。すなわち開放系としての人の 理解である。それは人と天地との相応の考え方に象徴されている。

本シンポジゥムでは, 鍼尒医学の特徵とその有用性㧍よび21世紀の医療への提言を東洋 医学の生命論の視点から考察するが, 可能なかぎり日常診療の中の事象に照らして考察し てみたい。

=629-03 京都府船井郡日吉町 明治鍼尒大学 $\approx 07717-72-1181$ キーワード : 東洋医学 生命観 鍼尒医学 開放系 $\mathrm{MEMO}$ 